\title{
ANALISIS IMPLEMENTASI REFORMASI BIROKRASI DALAM MEREALISASIKAN GOOD GOVERNANCE DAN PENCAPAIAN TARGET MILLENIUM DEVELOPMENT GOALS (STUDI KASUS PADA PEMERINTAH KOTA YOGYAKARTA)
}

\author{
Wiwin Kurniasari
}

\author{
IAIN Salatiga \\ wiwinkurniasar@yahoo.com
}

\begin{abstract}
This report aims to review the implementation of bureaucracy reform in realizing good governance and the target mdgs the city government yogyakarta.This research is considered as policy research associated with bureaucracy reform based on the minister of utilization state apparatus and bureaucratic reform no. 11 years 2011 .The research is municipal yogyakarta that is city administration reward challenged the highest in the management of governance se-indonesia given by the indonesian government index ( igi) since 2012-2014 with with get a rata-rata 6,8 index governance. The data in this research consisting of primary and secondary data.The method of analysis that used in this research is descriptive analytical, analysis techniques use also content analysis. The research results showed that the implementation of good governance of the Government of the city were in accordance with the regulations of the Minister for Administrative Reform and the bureaucratic State apparatus No. 11 in 2011.
\end{abstract}

Keyword: good governance, indonesian government index

\section{PENDAHULUAN}

Akhir tahun 2008 para pemimpin negara kelompok (G-20) telah melakukan pertemuan dengan agenda khusus yang membahas krisis global yang sedang terjadi. Pada pertemuan tersebut disepakati 5 (lima) langkah bersama, yakni penguatan transparansi dan akuntabilitas, penguatan regulasi (menyangkut pengaturan, pengawasan yang prudent, manajemen resiko, dan penegakannya), mendorong integritas pasar keuangan, memperkuat kerja sama internasional, serta reformasi institusi keuangan internasional. Jika dicermati hampir sebagian besar langkah-langkah tersebut berkait erat dengan problem governance, baik di sektor korporasi maupun publik. Ini membuktikan sebagian besar negara masih meyakini jika akar permasalahan terjadinya krisis global saat ini adalah problem governance. Problem governance itu sendiri sebenarnya bukan masalah baru bagi berbagai negara di dunia termasuk Indonesia. Seiring dengan terjadinya krisis multidimensi yang melanda Indonesia pada tahun 1997, hampir semua pihak sepakat pada satu hal yaitu salah satu penyebab pokok terjadinya krisis adalah buruknya tata laksana pemerintahan di Indonesia yang dibuktikan dengan tingginya praktik korupsi, kolusi, dan nepotisme $(\mathrm{KKN})$. Pembangunan yang berjalan manipulatif dan tidak berpihak kepada kepentingan rakyat, hanya berpihak pada kronikroni yang berada di lingkaran kekuasaan adalah merupakan bukti konkret bad governance di Indonesia.

Pada perkembangannya, perbaikan sektor ekonomi lebih fokus pada upaya perwujudan good governance yang diperkenalkan Bank Dunia pada dekade 90-an ketika mengatasi kemiskinan di Afrika. Seiring dengan kegagalan Pemerintahan Indonesia menghadapi krisis di dunia juga mulai terjadi kristalisasi paradigma yang bermuara pada satu pandangan bahwa pembangunan yang berorientasi pada pertumbuhan ekonomi adalah langkah gagal dalam mewujudkan pemerataan kesejahteraan seluruh rakyat, eksploitasi besar-besaran terhadap sumber daya alam untuk menunjang pertumbuhan sangat berbanding terbalik dengan sektor-sektor sosial yang cenderung terabaikan. Dengan mengambil contoh negara-negara dunia ketiga, badan-badan keuangan internasional mengambil prioritas untuk memperbaiki 
birokrasi pemerintahan di dunia ketiga dalam konsep good governance yang mulai diperkenalkan.

Namun berkali-kali dalam progress report MDGs di kawasan Asia Pasifik, Indonesia di kategorikan sebagai negara yang lamban langkahnya dalam mencapai MDGs di tahun 2015. Sumber pelambanannya ditunjukkan dari masih tingginya angka kematian ibu melahirkan, belum tuntasnya laju penularan HIV-AIDS, makin meluasnya laju deforestasi, rendahnya tingkat pemenuhan air minum dan sanitasi yang buruk, serta beban hutang luar negeri yang terus menggunung (UNESCAP, 2010). Fakta muram ini juga diperkuat dengan merosotnya kualitas hidup manusia Indonesia sebagaimana yang di laporkan Human Development Index jika pada tahun 2006 berada di posisi 107 tahun 2008 di posisi 109, tahun 2009 makin terpuruk di posisi 111, dan semakin terperosok di peringkat 124 pada tahun 2011. Berdasarkan survei USAID kualitas pelayanan publik di Indonesia saat ini adalah sebagai berikut:

1. Indeks Pembangunan Manusia urutan ke 121 dari 188 Negara pada tahun 2013 (UNDP).

2. Governance effectiveness index of 7 Asian Economies 1996-2012, urutan ke 7 setelah Vietnam.

3. Skor efisiensi birokrasi negara-negara asia, urutan 10 dari 12 negara yang disurvei tahun 2012. Skor tertinggi adalah Singapura.

4. Corruption perception index urutan 134 dari 175 negara Asia Pasifik (2013, Transparansi Internasional).

5. Kualitas kesehatan peringkat ke 6 dan kesehatan ke-7 dari 10 negara Asia Tenggara di bawah Singapura, Brunei Darussalam, Malaysia, Vietnam, Filiphina.

Walaupun upaya-upaya menuju pencapaian MDGs tidak harus menunggu terwujudnya prinsip-prinsip good governance, namun sulit membayangkan bahwa MDGs dapat tercapai tanpa diiringi oleh penerapan prinsip-prinsip good governance. Tata kelola pemerintahan adalah proses pembuatan dan implementasi kebijakan melalui interaksi antar empat arena "governance" yaitu pemerintah (government), birokrasi (bureaucracy), masyarakat sipil (civil soviety), dan masyarakat ekonomi (economic society). Oleh karena itu, kualitas dan kemajuan suatu tata kelola pemerintahan tidak hanya menjadi tanggung jawab pemerintah, melainkan juga seberapa jauh masing-masing arena mampu menerapkan prinsip-prinsip partisipasi, akuntabilitas, keadilan, transparansi, efisiensi, dan efektivitas.

Indonesian Governance Index (IGI) atau hasil pemeringkatan yang dituangkan dalam indeks tata kelola pemerintahan Indonesia yang menjadi lembaga indipenden non pemerintahan partnership merupakan perangkat komprehensif, terukur, dan kaya data sehingga perlu didorong untuk bisa menjadi rujukan bagi semua kalangan untuk mengevaluasi sejauh mana keberhasilan suatu pemerintahan daerah /kota dalam mengelola wilayahnya. Partnership for Governance Reform telah melakukan serangkaian analisis data publik dan persepsi di 34 Provinsi guna melihat sejauh mana kualitas sekaligus mengetahui kinerja implementasi good governance di satu daerah dengan daerah lain. Proses dan hasil dari kegiatan tersebut disajikan dalam sebuah indeks bernama IGI (Indonesia Governance Index). Partnership for Governance Reform (PGR) di Indonesia telah melakukan pemeringkatan tata kelola pemerintahan dengan pengukuran dilakukan terhadap 4 (empat) sektor pemerintahan yaitu, Eksekutif, Legislatif, Birokrasi, Masyarakat Sipil dan Dunia Usaha. Pengukuran keempat sektor tersebut telah diukur dengan menggunakan 6 (enam) parameter good governance yaitu akuntabilitas, transparansi, partisipasi, keadilan, efesiensi dan efektivitas. Pemerintah Kota Yogyakarta menjelang akhir 2014 dikukuhkan sebagai Pemerintah Kota yang memiliki indeks tertinggi dalam pengelolaan tata pemerintahan se-Indonesia. Penghargaan ini diberikan oleh Indonesian Government Indeks (IGI), penghargaan indeks tertinggi ini diberikan atas dasar survei langsung yang dilakukan lembaga itu sejak 2012-2013 dari 34 kabupaten/kota yang dinilai lembaga tersebut, Pemerintah Kota Yogyakarta memperoleh indeks tertinggi dengan mendapatkan nilai rata-rata 6,8 dalam indeks tata kelola pemerintahan. Sedangkan nilai ratarata 34 kabupaten/kota yang dinilai adalah 4,9. 
Makalah ini mencoba menelisik permasalahan tentang bagaimana implementasi reformasi birokrasi dalam merealisasikan good governance dan pencapaian target MDGs pada Pemerintah Kota Yogyakarta. Berdasarkan fokus kajian dan tujuan dari penelitian, maka diharapkan penelitian ini dapat memberikan manfaat sebagai berikut:

1. Kegunaan teoritis, penelitian ini diharapkan dapat memberikan kontribusi pemikiran bagi kementerian/lembaga maupun pemerintah daerah dan pemerintah kota dalam upaya mewujudkan reformasi birokrasi dalam merealisasikan good governance dan pencapaian target MDGs.

2. Kegunaan praktis, hasil penelitian ini diharapkan menjadi wawasan pemikiran bagi pemerintah daerah dan pemerintah kota dalam upaya mewujudkan reformasi birokrasi dalam merealisasikan good governance dan pencapaian target MDGs sehingga dapat meningkatkan peringkat Indonesian Governance Index (IGI).

3. Kegunaan akademis, hasil penelitian ini diharapkan dapat menjadi acuan atau referensi untuk penelitian selanjutnya.

\section{LANDASAN TEORI}

\section{Konsep Good Governance}

Pada pemahaman konsep good governance, pertama kaili diusulkan oleh Bank Dunia (World Bank), United Nation Development Programe (UNDP), Asian Development Bank (ADB) disebutkan bahwa tata kepemerintahan yang baik dalam dokumen UNDP adalah penggunaan wewenang ekonomi, politik dan administrasi guna mengelola urusanurusan negara pada semua tingkat. Tata pemerintahan mencakup seluruh mekanisme, proses, dan lembaga-lembaga di mana warga dan kelompok-kelompok masyarakat mengutarakan kepentingannya, menggunakan hak hukum, memenuhi kewajiban dan menjembatani perbedaan-perbedaan di antara warga dan kelompok masyarakat mengutarakan kepentingan mereka, menggunakan hak hukum, memenuhi kewajiban dan menjembatani perbedaan-perbedaan di antara mereka. Definisi lain dari Krina (2003) menyebutkan governance adalah mekanisme pengelolaan sumber daya ekonomi dan sosial yang melibatkan pengaruh sektor non pemerintah dalam suatu usaha kolektif. Definisi ini mengasumsikan banyak aktor yang terlibat dimana tidak ada yang sangat dominan yang menentukan gerak aktor lain. Governace mengakui bahwa di dalam masyarakat terdapat pusat pengambilan keputusan yang bekerja pada tingkat berbeda.

Menurut pemikiran Meuthia Ganie (1998) yang berangkat dari pendefinisian governance yang diarahkan sebagai tradisi dan institusi yang menjalankan kekuasaan di dalam suatu negara, termasuk (1) proses pemerintah dipilih, dipantau, dan digantikan, (2)kapasitas pemerintah untuk memfokuskan dan melaksanakan kebijakan secara efektif, dan (3) pengakuan masyarakat dan negara terhadap terhadap berbagai institusi yang mengatur interaksi antar mereka. Unsur yang terakhir dilakukan melalui tiga struktur komunikasi, yaitu kewenangan, legitimasi, dan representasi. Kewenagan adalah hak pemerintah untuk membuat keputusan dalam bidang tertentu. Walaupun ini merupakan hak dari suatu pemerintah modern, namun yang terpenting adalah bagaimana melibatkan persepsi rakyat tentang tindakan yang perlu dilakukan pemerintah. Legitimasi diperoleh karena masyarakat mengakui bahwa pemerintah telah menjalankan peranannya dengan baik, atau kinerja dalam menjalankan kewenangan itu tinggi. Representasi diartikan sebagai hak untuk mewakili pengambilan keputusan bagi kepentingan golongan lain dalam kaitannya dengan alokasi sumber daya. Oleh karena itu good governance pada akhirnya tidak terbatas pada menjalankan wewenang dengan baik semata, tetapi lebih penting lagi adalah bagaiman masyarakat dapat berpartisipasi dan mengontrol pemerintah untuk menjalankan wewenang tersebut dengan bik (accountable). Dengan demikian konsep good governance yang baik akan selalu didasarkan pada tiga pilar penyangga yang terdiri dari transparansi, akuntabilitas, dan partisipasi. Ketiga pilar tersebut dilengkapi oleh Asian Development Bank dengan pilar keempat yaitu predictability.

Meskipun diyakini oleh sebagian penulis bahwa istilah good governance telah digunakan jauh lebih awal, tetapi istilah ini baru kemudian 
menjadi perhatian berbagai pihak ketika IMF, UNDP dan World Bank memperkenalkannya. Berkenaan dengan pengertian good governance, UNDP, mendefinisikan good governance sebagai penggunaan wewenang politik, ekonomi dan adminsitrasi untuk mengelola urusan suatu bangasa pada semua tingkatan (the exercise of political, economic, and administrative authority). Sedangkan World Bank mendefinisikannya sebagai cara bagaimana kekuasaan negara digunakan dalam rangka mengelola sumber daya ekonomi dan sosial untuk kepentingan pembangunan dan masyarakat (the way state power is used in managing economic and social resources for development and society). Bila dicermati definisi di atas, tampak bahwa good gevernance menyiratkan bahwa pelaksanaan good governance hanya melibatkan pemerintah semata. Hal ini tentu menjadikan pengertian governance menjadi lebih sempit, terbatas pada pengelolaan birokrasi pemerintah. Itu sebabnya good governance diterjemahkan dalam bahasa Indonesia oleh berbagai penulis dan lembaga dengan penyelenggaraan pemerintahan yang amanah, pengelolaan pemerintahan yang baik dan bertanggungjawab (LAN), atau pemerintahan yang bersih. Tetapi, kemudian untuk kepentingan yang lebih luas, pengertian good governance kemudian mengalami perubahan orientasi menjadi lebih luas sehingga good governance tidak hanya pengelolaan birokrasi pemeritahan tetapi juga pengelolaan secara umum yang berkaitan dengan pelayanan publik. Hal ini dilakukan dengan meredefinisikan good governance. Meuthia Ganie misalnya mendefinisikan good governance sebagai kemekanisme pengelolaan sumber daya ekonomi dan sosial yang melibatkan pengaruh sektor negara dan sektor non-pemerintah dalam suatu usaha kolektif. Sedangkan Mardiasmo mendefinsikan good governance sebagai suatu penyelenggaraan manajemen pembangunan yang solid dan bertanggungjawab yang sejalan dengan prinsip demokrasi dan pasar yang efisien, penghindaran salah alokasi dana investasi, dan pencegahan korupsi baik secara politik maupun administratif, menjalankan disiplin anggaran serta penciptaan legal and political framework bagi tumbuhnya aktivitas usaha" Sebenarnya istilah good governance tidak hanya berkonotasi pengelolaan birokrasi pemerintahan saja, tetapi lebih luas dari itu, bisa mencakup seluruh pengelolaan baik pengelolaan pemerintahan maupun pengelolaan instansi atau organisasi swasta khususnya yang berkaitan dengan pelayanan umum. Bahkan istilah inipun juga dapat digunakan untuk menyebut pengelolaan organisasi perusahan bisnis yang berorientasi pencapaian profit dan untuk ini biasanya secara lengkap disebut good coorporate governance. Dengan demikian sesunggunya istilah governance lebih tepat diterjemahkan sebagai tata kelola. Namun harus diakui bahwa istilah good governance ini dalam pemakaian oleh para pengkaji lebih banyak digunakan dalam pembicaraan tata kelola pemerintahan yang baik. Hal ini juga disebabkan oleh karena diskusi tentang peran institusi dalam pembangunan didominasi oleh analisis mengenai peran negara. Apa yang dapat ditangkap dari deskripsi di atas ialah bahwa pengertian good governance menyiratkan bahwa penerepan istilah tersebut dalam kaitan perbaikan kondisi bangsa dari krisis multidimensional tidak hanya melibatkan pemerintah semata, tetapi juga seluruh komponen bangsa; pemerintah, dunia usaha, pegawai negeri, rakyat dan seluruh komponen bangsa. Dengan demikian banyak aktor yang terlibat dalam proses penerapan good governance sebagai upaya baru dalam membangun kembali bangsa dari krisis multidimensi. Dengan pemahaman ini berarti good gevernance adalah upaya seluruh komponen bangsa secara bersama-sama bersinergi yang dimotori oleh pemerintah melakukan tata kelola yang baik dalam mengelola sumber daya ekonomi dan sosial untuk tujuan pembangunan bangsa dan masyarakat. Upaya bersama komponen bangsa bersama pemerintah dalam mengelola sumber daya ekonomi dan sosial dapat berarti bahwa peran pemerintah tereduksi dalam batas-batas tertentu sehingga pemerintah lebih berperan sebagai mediator dan fasilitator dalam mewujudkan kepentingan masing-masing komponen bangsa. Dan sebaliknya akan meningkatkan peran dan partispasi komponen 
masyarakat dalam usaha pembangunan negara. Dengan demikian maka akan terjadi kesimbangan dalam melakukan tata kelola dalam usaha pencapaian tujuan negara. Kata good sebagai kata sifat yang diberika pada kata governance memberi arti bahwa tata kelola memiliki karakter: 1) nilai yang menjunjung tinggi keinginan atau kehendak rakyat serta nilai-nilai yang dapat meningkatkan kemampuan rakyat dalam mencapai tujuan nasional, kemandirian pembangunan yang berkelanjutan dan keadilan sosial, 2) aspek fungsional dari pemerintah yang efektif dan efisien dalam pelaksanaan tugasnya untuk mewujudkan tujuan nasional.

\section{Prinsip-Prinsip Good Governance}

Seorang pemerhati persoalan ini menginventarisir beberapa prinsip good governance dari beberapa lembaga. UNDP misalnya, merekomendasikan beberapa karakteristik governance, yaitu legitimasi politik, kerjasama dengan institusi masyarakat sipil, kebebasan berpartisipasi, akuntabilitas birokratis dan keuangan (financial), manajemen sektor publik yang efisien, kebebasan informasi dan ekspresi, sistem yudisial yang adil dan dapat dipercaya. World Bank mengungkapkan sejumlah karakteristik good governance antara lain masyarakat sipil yang kuat dan partisipatoris, terbuka, pembuatan kebijakan yang dapat diprediksi, eksekutif yang bertanggung jawab, birokrasi yang profesional dan taat aturan hukum. Masyarakat Transparansi Indonesia menyebutkan sejumlah indikator seperti :transparansi, akuntabilitas, kewajaran dan kesetaraan,serta kesinambungan. Sedangkan Asian Development Bank sendiri menegaskan adanya konsensus umum bahwa good governance dilandasi oleh 4 pilar yaitu:(1) Accountability,

Transparency, (3)Predictability, dan (4) Participation. Apa yang tampak dari inventarisasi prinsip-prinsip good governance yang dinyatakan oleh beberapa lembaga tersebut adalah bahwa prinsip-prinsip tersebut sangat beragam.

\section{Good Governance di Indonesia}

Di Indonesia masalah governance di sektor publik sudah mendapatkan perhatian yang cukup mendalam sejak pertengahan dekade 2000. Komite Nasional Kebijakan Governance (KNKG), yang dibentuk berdasarkan surat keputusan Menteri Koordinator Perekonomian RI No. KEP49/M.EKON/II/ TAHUN 2004,tanggal 30 November 2004 mempunyai tugas untik memperluas cakupan tugas sosialisasi corporate governance bukan hanya di sektor korporasi tetapi juga di sektor publik. Pada tahun 2008 KNKG berhasil menerbitkan Pedoman Umum Good Public Governance dengan tujuan untuk dijadikan acuan bagi lembaga-lembaga negara dan lembaga pemerintahan di Indonesia dalam melaksanakan good public governance antara lain dalam rangka untuk mendorong efektifitas penyelenggaraan negara serta mendorong timbulnya kesadaran dan tanggung jawab untu memajukan dan mengutamakan kesejahteraan rakyat.

Selain KNKG, pihak dari luar pemerintahan pun telah melakukan upaya-upaya pengidentifikasian prinsip-prinsip good public governance antara lain yang dilakukan oleh Kemitraan Bagi Pembaharuan Tata Pemerintahan (The Partnership for Governance Reform (PGR) yang bekerja sama dengan The Australian Agency for International Development (AusAID). Hasil kerja mereka antara lain berupa Indonesian Govenance Index (IGI), yaitu indeks kualitas penerapan good governance pada 34 pemerintah daerah di Indonesia (Gismar et al, 2013).

\section{Penelitian Terdahulu}

Penelitian yang terkait governance antara lain dilakukan Heyer (2011) yang menyatakan bahwa yang dimaksud dengan penerapan program new public management adalah melakukan sesuatu tindakan yang memang ditujukan untuk memperbaiki efisiensi dan efektifitas layanan publik serta organisasi layanan publik dengan mempunyai suatu pandangan atau nilai yang mengedapankan pertanggungjawaban dan perbaikan pemberian layanan publik. Perkembangan selanjutnya dari new public management adalah menuju apa yang disebut dengan nama new public governance yang diperkenalkan sebagai upaya untuk menghadapi permasalahan penerapan kebijakan publik dan pemberian layanan publik yang semakin komplek yang tidak bisa diatasi 
dengan hanya menerapkan new public management. Osborne (2011:6) membagi inti perhatian public governance menjadi lima sudut pandang yang saling berkaitan satu dengan yang lain yang mempengaruhi kualitas layanan public, yaitu berupa: (i)socio-political governance berfokus pada hubungan kelembagaan di dalam masyarakat, di mana pemerintah bukan lagi sebagai pihak yang paling berkuasa atau yang paling menentukan dalam penyusunan kebijakan publik tetapi harus memperhatikan masyarakat dan pelaku lainnya agar diakui dan dipatuhi oleh semua pihak, serta dapat memberikan pengaruh terhadap lingkungannya; (ii) public policy governance berfokus pada efektifitas dalam pelaksanaan administrasi publik sehingga dapat meliputi atau mencakup kerumitan permasalahan yang ada pada semua lini atau organisasi pemerintahan; (iii) contract governance, berfokus pada tata kerja new public management khususnya berkaitan dengan hubungan kontrak pengelolaan dalam pemberian layanan publik. (iv) network governance, berfokus pada bagaimana pengorganisasian secara otomatis jaringanjaringan antar organisasi dapat berfungsi, dengan peranan atau tanpa peranan pemerintah, dalam pelaksanaan pemberian layanan publik.

Usaha lainnya dalam pengidentifikasian good public governance adalah dilakukan oleh The International Federation of Accountants (IFAC) bekerja sama dengan The Chartered Institute of Public Finance Accountancy yang pada bulan Juni 2013 mengeluarkan draft dengan judul an International Framework of Good Governance in Public Sector. Prinsipprinsp penting good public governance yang diperkenalkan melalui draft ini berupa komitmen yang kuat terhadap integritas, nilai etika, dan ketaatan terhadap hokum serta adanya keterbukaan dan ketelitian dalam pelaksanaan tugas. Selain itu draft ini mengidentifikasikan bahwa fungsi utama dari penerapan good public governance adalah untuk memastikan bahwa organisasi sektor publik senantiasa bertindak bagi kepentingan masyarakat.

Earle dan Scott (2010) yang meneliti pengaruh governance terhadap usaha-usaha program kemiskinan dan terhadap hasil-hasil pembangunan di negara yang sedang berkembang. Hasil penelitian menunjukkan bahwa governance yang rendah berpengaruh negatif terhadap pertumbuhan ekonomi dan juga usaha-usaha pengurangan kemiskinan.

Menurut penelitiannya, Kaufman, Kraay, dan Zoido-Lobatón (2009) menyimpulkan bahwa terdapat hubungan langsung antara good governance, stable government, dan kondisi sosial-ekonomi. Riset dilakukan terhadap lebih dari 150 negara dengan menggunakan enam indikator, yaitu: (i) voice \& accountability, (ii) political instability \& violence, (iii) government effectiveness, (iv) regulatory burden, (v) rule of law dan (vi) graft. Dari berbagai indikator di atas, diperoleh ukuran yang disebut Worldwide Governance Indicators (WGI), yang dapat memberikan gambaran perbandingan antar negara dalam mengelola pemerintahannya. Berdasarkan penelitian tersebut, dapat dilihat perkembangan good governance Indonesia dalam periode 1998-2010 dengan enam indicator utama yakni control of corruption, political stability and absence of violence, voice accountability, rule of law, regulatory quality dan government effectiveness.

Di Indonesia penelitian yang dilakukan oleh Susanto dkk (2014) memperlihatkan hasil bahwa kualitas penerapan good governance pada suatu pemerintah daerah provinsi merupakan faktor yang berpengaruh positif terhadap kinerja pemerintah daerah dalam pemberian layanaan masyarakat. Adapun kualitas pemberian layanan publik diukur dengan menggunakan data indeks pembangunan manusia (IPM). Selain itu pertumbuhan perekonomian suatu daerah provinsi dan realisasi belanja provinsi per kapita mempunyai pengaruh positif terhadap kinerja pemerintah daerah, sedangkan besarnya produk domestik bruto (PDRB) tidak berpengaruh terhadap kinerja pemerintah daerah provinsi.

\section{METODOLOGI PENELITIAN}

Penelitian ini tergolong sebagai penelitian kebijakan yang terkait dengan reformasi birokrasi berdasarkan Peraturan Menteri Pendayagunaan Aparatur Negara dan Reformasi Birokrasi No. 11 Tahun 2011. Objek penelitian ini adalah Pemerintah Kota Yogyakarta yang merupakan Pemerintah Kota yang memiliki 
penghargaan indeks tertinggi dalam pengelolaan tata pemerintahan se-Indonesia yang diberikan oleh Indonesian Government Indeks (IGI) sejak tahun 2012-2013-2014 dengan dengan mendapatkan nilai rata-rata 6,8 dalam indeks tata kelola pemerintahan. Sumber data dalam penelitian ini terdiri dari data primer dan sekunder.

Metode analisis yang digunakan dalam penelitian ini bersifat deskriptif analitis, karena penelitian ini merupakan suatu upaya untuk mendeskripsikan implementasi dan kendala yang dihadapi dalam reformasi birokrasi dalam merealisasikan good governance dan pencapaian target MDGs pada Pemerintah Kota Yogyakarta dengan cara mengungkapkan dan memaparkan permasalahan, kemudian permasalahan tersebut akan dibahas dan dianalisa dengan kebijakan reformasi birokrasi berdasarkan Peraturan Menteri Pendayagunaan Aparatur Negara dan Reformasi Birokrasi No. 11 Tahun 2011 sehingga dapat memberikan gambaran secara menyeluruh dan sistematis. Analisis proses kebijakan (analysis of policy process), dimana dalam pendekatan ini, analisis dilakukan atas proses perumusan, penentuan agenda, pengambilan keputusan, adopsi, implementasi dan evaluasi dalam proses kebijakan. Jika dilihat dari item analisisnya, pendekatan ini lebih melihat kandungan (content) sebuah proses kebijakan. Terdapat tiga elemen dalam kebijakan yang menjadi target analisis, yakni: (1) faktor determinan utama; (2) isi kebijakan; dan (3) dampak kebijakan baik yang diharapkan maupun yang tidak diharapkan.

Teknik analisis yang digunakan juga melalui analisis isi (content analysis) adalah penelitian yang bersifat pembahasan mendalam terhadap isi suatu informasi tertulis atau tercetak dalam media massa. Pelopor analisis isi adalah Harold D. Lasswell, yang memelopori teknik symbol coding, yaitu mencatat lambang atau pesan secara sistematis, kemudian diberi interpretasi. Banyak variasi para ahli dalam memberi pengertian terhadap analisis isi (content analysis), secara umum diartikan sebagai metode yang meliputi semua analisis mengenai isi teks, tetapi di sisi lain analisis isi juga digunakan untuk mendeskripsikan pendekatan analisis yang khusus. Analisis isi merupakan suatu metode yang diterapkan dalam komunikasi untuk menganalisis isi pesan (teks). Analisis isi bersifat objektif, sistematis dan generalis. Objektif dalam artian menurut aturan atau prosedur yang apabila dilaksanakan oleh orang (peneliti) lain dapat menghasilkan kesimpulan yang serupa. Sistematis artinya penetapan isi atau kategori dilakukan menurut aturan yang diterapkan secara konsisten, Generalis artinya penemuan data harus memiliki referensi teoritis.

\section{HASIL DAN PEMBAHASAN}

Sasaran dan Indikator keberhasilan reformasi birokrasi berdasarkan Peraturan Menteri Pendayagunaan Aparatur Negara dan Reformasi Birokrasi No. 11 Tahun 2011 :

\section{Indeks Persepsi Korupsi (IPK)}

Transparency International (TI) yang berpusat di Berlin, Jerman setiap tahun menerbitkan Corruption Perception Index (CPI) atau Indeks Persepsi Korupsi (IPK). Peringkat IPK menunjukkan bagaimana persepsi korupsi sektor pemerintahan di suatu negara dibandingkan negara lainnya. Skala nilai I berkisar dari 0 sampai dengan 10 . Nilai 0 berarti dipersepsikan paling tinggi korupsinya dan nilai 10 dipersepsikan paling rendah korupsinya.

Survei dan assesmen yang digunakan untuk menetapkan IPK meliputi pertanyaan pertanyaan yang terkait dengan suap (bribery) oleh pejabat publik, komisi (kickbacks) dalam pengadaan barang dan jasa, penggelapan (embezzlement) dana-dana publik dan kekuatan dan kefektifan upaya-upaya anti korupsi. Setiap tahun TI-Indonesia juga menerbitkan IPK terhadap kota-kota di Indonesia dan indeks suap atas institusi pelayanan publik.

Pemerintah Kota Yogyakarta menduduki peringkat keempat dengan nilai IPK sebesar 5,81. Namun hal tersebut tidak lantas menjadikan kota ini puas begitu saja dengan hasil yang telah diperoleh. Upaya untuk meningkatkan skor, kedepannya, menjadi lebih penting guna mewujudkan pemerintahan yang lebih bersih dan baik. Selain membentuk unit pelayanan informasi keluhan masyarakat dengan menyediakan layanan sms serta hotline 
khusus, Pemerintah Kota Yogyakarta juga berupaya menerapkan cara-cara manusiawi melalui pola insentif-disentif bagi pegawai sebagai salah satu solusi untuk mengatasi tindak korupsi.

\section{Opini BPK}

Opini merupakan pernyataan profesional pemeriksa mengenai kewajaran informasi keuangan yang disajikan dalam laporan keuangan yang didasarkan pada kriteria (i) kesesuaian dengan standar akuntansi pemerintahan, (ii) kecukupan pengungkapan (adequate disclosures), (iii) kepatuhan terhadap peraturan perundang-undangan, dan (iv) efektivitas sistem pengendalian intern. Kriteria opini oleh Badan Pemeriksa Keuangan (BPK) adalah sebagai berikut:

Tabel 1: Jenis Opini Badan Pemeriksa Keuangan

\begin{tabular}{|c|c|c|}
\hline No & Jenis Opini & Keterangan \\
\hline 1 & $\begin{array}{l}\text { Wajar } \\
\text { Pengecualian (WTP) }\end{array}$ & $\begin{array}{l}\text { Auditor tidak memiliki reservasi tentang laporan keuangan } \\
\text { pemerintah. Keempat kriteria di atas terpenuhi. WTP ini juga } \\
\text { dikenal sebagai pendapat bersih, berarti bahwa laporan } \\
\text { keuangan disajikan secara wajar (fair). }\end{array}$ \\
\hline 2 & $\begin{array}{l}\text { Wajar Dengan } \\
\text { Pengecualian (WDP) }\end{array}$ & $\begin{array}{l}\text { Masih ada penggunaan keuangan negara yang bersifat } \\
\text { material yang menyimpang dari standar akuntansi } \\
\text { pemerintahan dan peraturan perundangan yang berlaku. }\end{array}$ \\
\hline 3 & $\begin{array}{l}\text { Opini Tidak Wajar } \\
\text { (adversed opinion) }\end{array}$ & $\begin{array}{l}\text { Jenis opini audit yang menyatakan bahwa laporan bahwa } \\
\text { laporan keuangan tidak menyajikan secara wajar posisi } \\
\text { keuangan, realisasi angaran, dan perubahan psosisi keuangan } \\
\text { sesuai dengan prinsip akuntansi yang berlaku umum. }\end{array}$ \\
\hline 4 & $\begin{array}{l}\text { Pernyataan Menolak } \\
\text { Memberikan Opini } \\
\text { (disclaimer of opinion) }\end{array}$ & $\begin{array}{l}\text { Banyak rekening/perkiraan pos/pos mata anggaran yang tidak } \\
\text { didukung denganbuku, catatan, dan bukti transaksi, atau } \\
\text { sekalipun buku, catatan, dan bukti transaksi ada, pihak } \\
\text { pemeriksa mengalami kesulitas untuk menelusuri alur } \\
\text { dokumen (flow of document) dan banyak hal-hal yang } \\
\text { menyimpang dari peraturan dan perundangan yang ada. }\end{array}$ \\
\hline
\end{tabular}

Pemerintah Kota Yogyakarta masih mempertahankan predikat opini Wajar Tanpa Pengecualian (WTP) dari Badan Pemeriksa Keuangan (BPK) sejak tahun 2009 hingga 2015 ini. Meskipun demikian Pemerintah Kota Yogyakarta masih menyisahkan beberapa catatan yang dituangkan dalam paragraf penjelasan. Laporan yang diserahkan BPK terdiri dari tiga laporan yaitu Laporan Hasil Pemeriksaan (LHP) atas Laporan Keuangan, LHP atas Kepatuhan terhadap Peraturan Perundang-undangan, dan LHP atas Sistem Pengendalian Intern. BPK RI memberikan opini mengenai kewajaran informasi yang disajikan dalam laporan keuangan. Pertimbangan dalam pemberianan opini atas laporan keuangan antara lain kesesuaian dengan Standar Akutansi Pemerintahan, kecukupan pengungkapan, kepatuhan terhadap peraturan perundang-undangan serta efektivitas sistem pengendalian intern.

\section{Integritas Pelayanan Publik}

Skor integritas ini didasarkan panda nilai rata-rata dari dua variabel, 6 (enam) indikator dan $18 \mathrm{sub}$ indikator. Kedua variabel yang digunakan adalah pengalaman integritas (experienced integrity) dan potensi integritas (potential integrity) dengan bobot yang telah ditentukan dari hasil kompilasi pendapat sejumlah pakar. Pengalaman integritas merefleksikan pengalaman faktor-faktor yang berpotensi menjadi penyebab terjadinya korupsi berdasarkan pengalaman atau penilaian responden. Secara lebih detail, survei KPK tersebut menurunkan kedua variabel di atas menjadi 6 (enam) indikator yaitu: (1) pengalaman korupsi, (2) cara pandang terhadap korupsi, (3) lingkungan kerja, (4) sistem administrasi, (5) perilaku individu, dan (6) pencegahan korupsi. Untuk mengoperasionalakan ke-enam indikator di atas KPK menggunakan 18 sub indikator yang 
terdiri dari: (1) frekuensi pemberian gratifikasi, (2) jumlah/besaran gratifikasi (3) waktu pemberian gratifikasi, (4) arti pemberian gratifikasi, (5) tujuan pemberian gratifikasi, (6) kebiasaan pemberian gratisikasi, (7) kebutuhan pertemuan di luar prosedur, (8) keterlibatan calo, (9) fasilitas di sekitar lingkungan pelayanan, (10) suasana/kondisi di sekitar pelayanan, (11) kepraktisan SOP, (12) keterbukaan informasi, (13) pemanfaatan teknologi informasi,

(14) keadilan dalam layanan, (15) ekspektasi petugas terhadap gratifikasi, (16) perilaku pengguna layanan, (17) tingkat/upaya anti korupsi, dan

mekanisme pengaduan masyarakat.

\section{Peringkat Kemudahan Berusaha} World Bank melalui groupnya, International Finance Corporation (IFC) mengadakan survei untuk mengetahui persepsi tentang kemudahan berusaha di suatu negara. Survei ini sudah dimulai sejak tahun 2004 dan menilai berbagai peraturan yang mempengaruhi 10 aspek bisnis sehari - hari, yaitu:

Tabel 2: Aspek Bisnis

\begin{tabular}{|c|c|c|}
\hline No & Aspek Bisnis & Keterangan \\
\hline 1 & Starting a business & $\begin{array}{l}\text { Aspek ini menilai semua prosedur resmi yang diperlukan bagi pengusaha } \\
\text { untuk memulai dan mengoperasikan sebuah usaha komersial. Ini termasuk } \\
\text { waktu yang diperlukan untuk mendapatkan semua perijinan untuk memulai } \\
\text { usaha. }\end{array}$ \\
\hline 2 & $\begin{array}{l}\text { Dealing } \\
\text { licenses }\end{array}$ & $\begin{array}{l}\text { Aspek ini mencatat semua prosedur yang diperlukan untuk bisnis di industri } \\
\text { konstruksi untuk membangun sebuah gudang standar. Prosedur ini termasuk } \\
\text { menyerahkan semua dokumen proyek spesifik yang relevan (misalnya, } \\
\text { rencana pembangunan dan situ peta) kepada pihak yang berwenang; } \\
\text { memperoleh semua izin yang diperlukan, dan sertifikat; menyelesaikan } \\
\text { semua pemberitahuan yang diperlukan, dan menerima semua pemeriksaan } \\
\text { yang diperlukan. Aspek ini juga menilai prosedur untuk mendapatkan } \\
\text { sambungan listrik, air, dan lahan. }\end{array}$ \\
\hline 3 & $\begin{array}{l}\text { Employing } \\
\text { workers }\end{array}$ & $\begin{array}{l}\text { Aspek ini menilai peraturan perundang-undangan tentang tenaga kerja, } \\
\text { misalnya peraturan terkait dengan rekruitmen, upah minimum, rigiditas jam } \\
\text { kerja, dan prosedur dan biaya pemberhentian tenaga kerja. }\end{array}$ \\
\hline 4 & $\begin{array}{l}\text { Registering } \\
\text { property }\end{array}$ & $\begin{array}{l}\text { Aspek ini menilai prosedur dan waktu yang diperlukan oleh pembeli untuk } \\
\text { membeli sebuah property dan perpindahan hak milik untuk nama pembeli } \\
\text { sehingga pembeli bisa menggunakan property ini untuk mengembangkan } \\
\text { usaha, menggunakan property sebagai jaminan dan menjual properti ke bisnis } \\
\text { lain. }\end{array}$ \\
\hline 5 & Getting credit & $\begin{array}{l}\text { Aspek ini melihat berfungsi tidaknya system kolateral dan kepailitas dalam } \\
\text { mendukung pembiayaan usaha. Ini menyangkut hak-hak hukum para } \\
\text { peminjam dan kreditur terhadap akses sumber-sumber keuangan. }\end{array}$ \\
\hline 6 & $\begin{array}{l}\text { Protecting } \\
\text { investors }\end{array}$ & $\begin{array}{l}\text { Aspek ini pada dasarnya berisi peraturan atau kebijakan untuka melindungi } \\
\text { kepentingan pemegang saham minoritas akibat penyalahgunaan kekayaan } \\
\text { perushaan untuk keuntungan pribadi dalam perlindungan kepentingan } \\
\text { investor, transparansi atas transaksi yang saling berhubungan (related-party } \\
\text { transaction), kewajiban direksi dan kemampuan pemegang saham untuk } \\
\text { menuntut direksi atas salah urus korporasi. }\end{array}$ \\
\hline 7 & Paying taxes & $\begin{array}{l}\text { Aspek ini merupakan seluruh jenis pajak (pajak peghasilan korporasi, pajak } \\
\text { bumi dan bangunan, pajak deviden, pajak capital gains, aapajak transaksi } \\
\text { keuangan, pajak pemungutan sampah, pajak kendaraan dan lain-lain, } \\
\text { kewajiban sosial dan beban administrasi ynag harus dibayar oleh usaha } \\
\text { menengah dalam pereiode fiskal tertentu. }\end{array}$ \\
\hline
\end{tabular}


$8 \quad$ Trading borders

$9 \quad$ Enforcing

contracts

10 Closing a business
Aspek ini aspek berisi prosedur, persyaratan (dokumen), biaya, dan waktu yang diperlukan dalam ekspor dan impor barang ke/dari negara lain. Untuk barang ekspor menyangkut prosedur, persyaratan (dokumen), biaya dan waktu mulai dari penyiapan barang di gudang sampai dengan pengiriman barang tersebut dari pelabuhan. Sebaliknya untuk impor barang menyangkut prosedur, persyaratan (dokumen), biaya dan waktu sejak barang sudah sampai di pelabuhan sampai dengan ke gudang importer.

Aspek ini menyangkut efisiensi system peradilan berupa lagkah-langkah, prosedur formal dan peraturan di sebuah negara dalam menyelesaiakan sengketa bisnis.

Aspek ini merupakan system kepailitan dan penutupan sebuah usaha. Hal ini terkait dengan waktu, biaya, dan hasil (outcome) dari kebangkrutan suatu usaha yang melibatkan institusi domestik.

\section{Sumber: World Bank, 2009}

Menurut Bank Dunia (2009), Indonesia dapat menekan jumlah hari untuk memulai bisnis dari 105 hari pada tahun 2008 menjadi 76 hari pada tahun 2009. Biaya yang harus dikeluarkan pengusaha untuk meulai usaha di Indonesia pun semakin rendah, yaitu dari $80 \%$ income per kapita di tahun 2008 menjadi $77,9 \%$ income per kapita di tahun 2009, atau menurun sebesar $2,62 \%$ selama periode 2008 2009. Sementara dalam hal perdagangan internasional, Indonesia dapat menyederhanakan jumlah dokumen yang dibutuhkan dan waktu pengurusan dokumen ekspor-impor, yaitu ekspor dari 7 menjadi 5 dokumen sehingga dapat memangkas waktu ekspor dari 25 menjadi 21 hari dan impor dari 9 menjadi 5 dokumen sehingga dapat memangkas waktu impor dari 30 menjadi 27 hari.

\section{Instansi Pemerintahan yang Akuntabel}

Ruang lingkup evaluasi akuntabilitas kinerja pemerintah dilakukan oleh Kementerian Pendayagunaan Aparatur Negara dan Reformasi Birokrasi meliputi:

a. Evaluasi atas penerapan Sistem Akuntabilitas Kinerja Instansi Pemerintah (SAKIP) dan pencapaian kinerja organisasi, dan

b. Penyusunan pemeringkatan hasil evaluasi pemerintah pusat dan daerah.

Evaluasi akuntabilitas kinerja instansi pemerintah terdiri atas evaluasi penerapan komponen manajemen kinerja (Sistem AKIP) yang meliputi: a. perencanaan kerja, b. pengukuran kinerja, c. evaluasi kinerja, d. pelaporan kinerja, e. capaian kinerja.

Komponen, sub komponen dan bobot untuk masing-masing komponen secara lengkap dapat terlihat pada tabel berikut:

Tabel 3: Komponen dan Sub Komponen

\begin{tabular}{|c|c|c|c|}
\hline No & Komponen & Sub Komponen & $\begin{array}{c}\text { Bobot } \\
\text { Penilaian }\end{array}$ \\
\hline \multirow[t]{2}{*}{1} & $\begin{array}{l}\text { Perencanaan } \\
\text { kinerja }\end{array}$ & $\begin{array}{l}\text { a. Rencana strategis, meliputi pemenuhan } \\
\text { renstra, kualitas dan implementasi renstra. } \\
\text { b.Rencana kinerja tahunan (RKT), meliputi } \\
\text { pemenuhan RKT, Kualitas RKT, dan } \\
\text { implentasi RKT. }\end{array}$ & $30 \%$ \\
\hline & & $\begin{array}{llr}\text { c.Penetapan kinerja }(\mathrm{PK}), & \text { meliputi: } \\
\text { pemenuhan } \mathrm{PK}, \quad \text { kualitas } & \mathrm{PK}, \text { dan } \\
\text { implementasi PK. } & & \end{array}$ & \\
\hline
\end{tabular}

2 Pengukuran kinerja
a.Pemenuhan pengukuran,
b.Kualitas pengukuran,
c.Implementasi pengukuran.

$20 \%$ 

3 Pelaporan kinerja
a. Pemenuhan pelaporan,
$10 \%$
b. Penyajian informasi kinerja,
$4 \quad$ Evaluasi kinerja
c. Pemanfaatan informasi kinerja.
a. Pemenuhan evaluasi,
$20 \%$
b. Kualitas evaluasi,
c. Pemanfaatan hasil evaluasi.
$5 \quad$ Capaian kinerja
a. Kinerja yang dilaporkan (output),
b. Kinerja yang dilaporkan (outcome),
c. Kinerja lainnya.

\section{Sumber: MenPAN No. 11 Tahun 2011}

\section{KESIMPULAN}

Kesimpulan dari makalah ini memperlihatkan pelaksanaan good governance Pemerintah Kota Yogyakarta telah sesuai dengan Peraturan Menteri Pendayagunaan Aparatur Negara dan Reformasi Birokrasi No. 11 Tahun 2011 tentang Indeks Persepsi Korupsi (IPK) Pemerintah Kota Yogyakarta menduduki peringkat keempat dengan nilai IPK sebesar 5,81. Namun hal tersebut tidak lantas menjadikan kota ini puas begitu saja dengan hasil yang telah diperoleh. Upaya untuk meningkatkan skor, kedepannya, menjadi lebih penting guna mewujudkan pemerintahan yang lebih bersih dan baik. Selain membentuk unit pelayanan informasi keluhan masyarakat dengan menyediakan layanan sms serta hotline khusus, Pemerintah Kota Yogyakarta juga berupaya menerapkan cara-cara manusiawi melalui pola insentif-disentif bagi pegawai sebagai salah satu solusi untuk mengatasi tindak korupsi. Opini oleh Badan Pemeriksa Keuangan (BPK) Wajar Tanpa Pengecualian (WTP), Integritas Pelayanan Publik Skala penilaian dimulai dari angka 1 sampai dengan 10 . Interpretasi dari nilai tersebut adalah semakin mendekati angka 10 berarti semakin baik integritas sektor publik, Peringkat Kemudahan Berusaha, Efektivitas pemerintahan, Instansi Pemerintahan yang Akuntabel melalui evaluasi akuntabilitas kinerja instansi pemerintah terdiri atas evaluasi penerapan komponen manajemen kinerja (Sistem AKIP) yang meliputi: a. perencanaan kerja, b. pengukuran kinerja, c. evaluasi kinerja, d. pelaporan kinerja, e. capaian kinerja.

\section{DAFTAR PUSTAKA}

Archon, Fung \& Erik Olin Wright, (2003), Deepening Democracy :

Institutional Innovations in Empowered Participatory Governance, The Real Utopias Project IV, London : Verso.

Budiardjo Miriam, (2000), Menggapai Kedaulatan untuk Rakyat, Bandung : Mizan.

Citizen Report Card, Panduan Monitoring Pelayanan Publik Berbasis Masyarakat, Panduan Pelatihan (2009). Lokal Government Support Program (LGSP)An USAID Project.

Earle, Lucy., dan scott, Zoe. 2010. Assessing the Evidance of Impact of Governance on Development Outcomes and Proverty Reduction. UK: Governance and Social Development Resource Centre.

Gismar, Abdul Malik et al., 2013 Towards a Well-Informed Society and Responsive Government: Executive Report Indonesia Governance Index 2012. Jakarta Indonesia: The Patnership for Governance Reform.

Heyer, Garth., 2011. New Public Management, a Stategy for Democratic Police Reform in Transitioning and Developing Countries. International Journal of Police Strategies \& Management, 34(3):419-433.

International Federation of Accountants (IFAC) and The Chartered Institute of Public Finance \& Accoountancy. 2013. Consulting Draft Juni 2013: Good Governance in the Public Sector an International Framework.

Kaufman, D., Kraay, A. and Zoido-Lobatón, P., 2009, Agregating Governance 
Indicators, World Bank Report, Washington DC, USA .

Komite Nasional Kebijakan Governance (KNKG). 2008. Pedoman Umum Good Public Governance, http://knkgindonesia.com/home/, diunduh pada tanggal 9 Mei 2015, pk.05.00.

Loina Lalolo Krina, Indikator dan Alat Ukur Prinsip Akuntabilitas, Transparansi, dan Partisipasi : Sekretariat Good Public Governance badan Pembangunan Nasional, Jakarta. 2003:hal.3.

Meuthia Ganie, Good Governance dan Tiga Struktur Komunikasi Rakyat dan Pemerintah, makalah yang disajikan pada Seminar Good Governance dan Reformasi Hukum di Jakarta, 1998.

Osborne, Stephen P., 2010. The New Public Governance. Emerging Perspectives on The Theory and Practice of Public Governance. London: Routledge.

Peters, B.Guy, (2000) The Politics of Bureaucracy, London : Routledge.

Rashidpour, Ali., \& Mazaheri M.Mahdi., 2013. Evaluation of Agency and Stewardship Approach in four units of the Islamic azad University and Prediction of Their Potential Productivity. Arabian Journal of Bussiness, and Mnagement Review, 3(5): 34-42.

Susanto, Dwi., Yusuf, Dian Anggraeni., dan Rachmawati, Yuanita., 2014. Pengaruh Good Governance terhadap kualitas Pemberian layanan Publik. Jurnal
Paradigma Vol 12. No. 02, Agustus 2014 -januari $2015: 73$.

World Bank, Good

Governanceand Development, Washington DC. 1992.

Modul Transparansi dan Akuntabilitas (2010). Basic Education Capacity - A Wordl Bank Project.

Modul Standarisasi Layanan Pendidikan (2010). Basic Education Capacity - A Wordl Bank Project.

Modul Penganggaran Berbasis Kinerja (2009). Local Government Supoort Program (LGSP) - An USAID Project.

Peraturan Menteri Negara Pendayagunaan Aparatur Negara dan Reformasi Birokrasi No.13 Tahun 2009 tentang Pedoman Peningkatan Kualitas Pelayanan Publik dengan Partisipasi Masyarakat.

Racmat Kriyantono, Teknik Praktis Riset Komunikasi; Disertai Contoh Praktis Riset Media, Public Relations, Advertising, Komunikasi Organisasi, Komunikasi Pemasaran, (Jakarta: Kencana, 2008) h. 251

UNESCAP(United Nations Economic and Social Commission for Asia and Pacific), $\mathrm{ADB}($ Asian Development Bank), UNDP(United Nations Development Programme), Achieving the MDGs in Era of Global Uncertainty. 2010 